\begin{abstract}
Corynebacterium epidermidicanis sp. nov., isolated from skin of a dog

Correspondence

Hans-Jürgen Busse

hans-juergen.busse@vetmeduni. ac.at

\author{
Alexa Frischmann, ${ }^{1}$ Alexander Knoll, ${ }^{1}$ Friederike Hilbert, ${ }^{2}$ \\ Aleksandra Anna Zasada, ${ }^{3}$ Peter Kämpfer ${ }^{4}$ and Hans-Jürgen Busse ${ }^{1}$ \\ ${ }^{1}$ Institut für Bakteriologie, Mykologie und Hygiene, Veterinärmedizinische Universität, A-1210 Wien, \\ Austria \\ ${ }^{2}$ Institut für Fleischhygiene, Fleischtechnologie und Lebensmittelwissenschaften, \\ Veterinärmedizinische Universität, A-1210 Wien, Austria \\ ${ }^{3}$ Department of Bacteriology, National Institute of Public Health, National Institute of Hygiene, \\ 00-791 Warsaw, Poland \\ ${ }^{4}$ Institut für Angewandte Mikrobiologie, Justus-Liebig-Universität Giessen, D-35392 Giessen, \\ Germany
}

A Gram-stain-positive, pleomorphic, oxidase-negative, non-motile isolate from the skin of a dog, designated strain $410^{\top}$, was subjected to comprehensive taxonomic characterization. Comparison of the 16S rRNA gene sequences revealed that the novel isolate showed highest similarities to the type strains of Corynebacterium humireducens, Corynebacterium diphtheriae, Corynebacterium pseudotuberculosis and Corynebacterium ulcerans (96.1-96.8\%). The quinone system consisted predominantly of MK- $8\left(\mathrm{H}_{2}\right)$ and MK- $9\left(\mathrm{H}_{2}\right)$. The polar lipid profile of strain $410^{\top}$ contained the major compounds diphosphatidylglycerol, phosphatidylglycerol, phosphatidylinositol, two unidentified phospholipids and four unidentified glycolipids. The polyamine pattern was composed of the major amines spermidine and spermine. In the fatty acid profile, predominantly straight-chain, saturated and mono-unsaturated fatty acids were detected $\left(\mathrm{C}_{18: 1} \omega 9 c, \mathrm{C}_{16: 1} \omega 7 c, \mathrm{C}_{16: 0}\right)$. These chemotaxonomic traits are in agreement with those reported for representatives of the genus Corynebacterium. Strain $410^{\top}$ tested negative for diphtheria toxin. Physiological properties as well as unique traits in the polar lipid profile could be used to distinguish strain $410^{\top}$ from the most closely related species. These data suggest that strain $410^{\top}$ represents a novel species of the genus Corynebacterium, for which we propose the name Corynebacterium epidermidicanis sp. nov. The type strain is $410^{\top}\left(=\mathrm{DSM} 45586^{\top}=\mathrm{LMG}\right.$ $26322^{\top}=$ CCUG $60915^{\top}$ ).
\end{abstract}

Currently, the genus Corynebacterium comprises more than 80 recognized species of which six were proposed in 2010: Corynebacterium canis (Funke et al., 2010a), Corynebacterium marinum (Du et al., 2010), Corynebacterium mustelae (Funke et al., 2010b), Corynebacterium pilbarense (Aravena-Roman et al., 2010), Corynebacterium pyruviciproducens (Tong et al., 2010) and Corynebacterium stationis (Bernard et al., 2010). The majority of representatives of the genus contain short chain mycolic acids (22-38 carbons; Collins et al., 1982a) but mycolic acids are absent in five species: Corynebacterium amycolatum, Corynebacterium atypicum, Corynebacterium caspium, Corynebacterium ciconiae and Corynebacterium kroppenstedtii (Collins et al., 1988, 1998, 2004; FernándezGarayzábal et al., 2004; Hall et al., 2003). The quinone

Abbreviation: NP, p-nitrophenyl.

The GenBank/EMBL/DDBJ accession number for the 16S rRNA gene sequence of strain $410^{\top}$ is FR874223. system is composed of dihydrogenated menaquinones with eight or nine isoprenoid units in the side-chain $\left[\mathrm{MK}-8\left(\mathrm{H}_{2}\right)\right.$, MK-9 $\left(\mathrm{H}_{2}\right)$ or a mixture of both] (Collins \& Jones, 1981). The fatty acid profiles consist predominantly of straightchain saturated and mono-unsaturated fatty acids but some species also contain tuberculostearic acid (Collins et al., 1982b). The peptidoglycan type is Al $\gamma$ with the diagnostic diamino acid meso-diaminopimelic acid (Schleifer \& Kandler, 1972). Although several species of the genus are well-known pathogens of humans and animals, including mammals and birds, species have been also isolated from other sources such as activated sludge and soil.

During the course of a study dealing with the classification of bacterial strains considered to be commensals that were isolated from primary cultures of veterinary specimens taken from individuals with different diseases, strain $410^{\mathrm{T}}$ attracted our attention. Strain $410^{\mathrm{T}}$ was isolated from the 
skin of a dog with pruritus after primary cultivation on blood agar. Colony counts of this strain were significant among the predominant colonies of $\beta$-haemolytic streptococci and Proteus strains (identified during routine diagnosis). The strain was grown aerobically on PYE agar ( $0.3 \%$ peptone from casein, $0.3 \%$ yeast extract, $1.5 \%$ agar, $\mathrm{pH}$ 7.2) or the corresponding broth medium at $28^{\circ} \mathrm{C}$. Anaerobic growth was tested in an anaerobic jar using AnaeroGen (Oxoid). Gram-behaviour was examined by staining as described by Murray et al. (1994) following the Hucker method and $\mathrm{KOH}$-lysis test as described by Moaledj (1986). Cell morphology was observed under an Olympus Provis AX70 microscope at $\times 1000$ magnification. In both tests, Gram-behaviour was positive. The cells exhibited a pleomorphic shape (coccoid and rod-shaped). The presence of catalase was tested using $3 \%(\mathrm{v} / \mathrm{v}) \mathrm{H}_{2} \mathrm{O}_{2}$; the test revealed the presence of catalase. Lipophilic behaviour was tested on brain heart infusion agar supplemented with $1 \%(\mathrm{v} / \mathrm{v})$ Tween 80 and strain $410^{\mathrm{T}}$ was shown not to be lipophilic. The CAMP reaction was tested on Columbia agar supplemented with $5 \%$ sheep blood with Staphylococcus aureus ATCC 25923; the CAMP reaction with strain $410^{\mathrm{T}}$ was positive. Biochemical identification was performed by the API Coryne system (bioMérieux) according to the instructions of the manufacturer. For appraisal of the resulting biochemical profile, apiweb identification software was used. The obtained code was 2100124, indicating a good identification at the genus level.

The 16S rRNA gene sequence was amplified as described by Buczolits et al. (2008) using the universal primers $27 \mathrm{f}$ and 1492r (Lane, 1991) but GoTaq Flexi DNA Polymerase (Promega) was used in PCR. Sequencing was carried out as described by Hilbert et al. (2010). The nearly complete sequence (1439 bases) was compared to gene bank entries using the EzTaxon server (Chun et al., 2007) and FASTA (Pearson \& Lipman, 1988). The nearest relatives were Corynebacterium diphtheriae NCTC $11397^{\mathrm{T}}$ (96.7 and $96.3 \%$ similarity, respectively), Corynebacterium pseudotuberculosis CIP $102968^{\mathrm{T}}$ (96.6 and $96.3 \%$ similarity, respectively), Corynebacterium humireducens MFC- $5^{\mathrm{T}}$ (96.8 and $96.2 \%$, respectively) and C. ulcerans NCTC $7910^{\mathrm{T}}$ (96.7 and $96.1 \%$ similarity, respectively). These data clearly demonstrate that strain $410^{\mathrm{T}}$ is a member of the genus Corynebacterium but do not suggest affiliation of strain $410^{\mathrm{T}}$ to any currently recognized species. Multiple alignment of sequences of type strains sharing $95 \%$ or higher similarity in the EzTaxon comparison was performed using CLUSTAL_X (Thompson et al., 1997) and manually edited for ambiguous bases and gaps using BioEdit (Hall, 1999). The phylogenetic position of strain $410^{\mathrm{T}}$ was examined by the maximum-likelihood, maximum-parsimony and neighbour-joining algorithms implemented in the PHYLIP package (Felsenstein, 2009) applying standard adjustments. Using the maximum-likelihood algorithm, strain $410^{\mathrm{T}}$ branched at the root of the clade with which the type species of the genus, $C$. diphtheriae, was affiliated (Fig. 1); this position was also supported in the neighbour-joining and maximum-parsimony trees (results not shown). This branching was not supported by significant bootstrap values (24-54\%). However, phylogenetic analyses confirm assignment of strain $410^{\mathrm{T}}$ to the genus Corynebacterium but separate from any recognized species.

For production of biomass for analyses of mycolic acids, quinones, polar lipids and polyamines, strain $410^{\mathrm{T}}$ was grown at $28{ }^{\circ} \mathrm{C}$ in PYE broth $(0.3 \%$ peptone from casein, $0.3 \%$ yeast extract, $\mathrm{pH} 7.2$ ) and the reference strains were grown in $3.3 \times$ PYE broth $(0.99 \%$ peptone from casein, $0.99 \%$ yeast extract, $\mathrm{pH} 7.2$ ). For extraction of mycolic acids, $50 \mathrm{mg}$ lyophilized biomass was suspended in a mixture of $2.5 \mathrm{ml}$ methanol, $2.5 \mathrm{ml}$ toluene and $0.1 \mathrm{ml}$ concentrated sulphuric acid and incubated for $16 \mathrm{~h}$ at $75{ }^{\circ} \mathrm{C}$ in a tightly closed tube. After cooling down to $4{ }^{\circ} \mathrm{C}$, the mixture was shaken thoroughly with $1 \mathrm{ml}$ hexane. After phase separation, the hexane phase containing mycolic acids was collected and passed through a column containing $\mathrm{NH}_{4} \mathrm{HCO}_{3}$ to remove sulphuric acid. The hexane phase was taken to dryness under a stream of nitrogen and then dissolved in a final volume of $100 \mu \mathrm{l}$ hexane. Approximately $50 \mu \mathrm{l}$ of the extract was spotted on a silica gel 60 thin layer plate $(200 \times 200 \mathrm{~mm}$, thickness $0.2 \mathrm{~mm}$; Macherey-Nagel $)$ and developed in a mixture of petroleum ether $\left(35-60{ }^{\circ} \mathrm{C}\right)$ : acetone (95:5). Mycolic acids were detected by spraying with $5 \%$ ethanolic molybdatophosphoric acid followed by heating at $160{ }^{\circ} \mathrm{C}$ for $15 \mathrm{~min}$. Polar lipids and quinones were extracted and analysed applying the integrated procedure reported by Tindall (1990a, b) and Altenburger et al. (1996). Polyamines were extracted as reported by Busse \& Auling (1988) and Altenburger et al. (1997). For HPLC analyses of quinones and polyamines, the equipment used was as reported by Stolz et al. (2007).

Strain $410^{\mathrm{T}}$ was shown to contain corynemycolic acids that exhibited a slightly higher $R_{\mathrm{f}}$ value than those detected in C. diphtheriae DSM $20524^{\mathrm{T}}$ (results not shown).

The quinone system of strain $410^{\mathrm{T}}$ was composed of MK-8 $\left(\mathrm{H}_{2}\right)(70 \%)$, MK-9 $\left(\mathrm{H}_{2}\right)(26 \%)$ and MK-7 $\left(\mathrm{H}_{2}\right)(4 \%)$, which supports affiliation to the genus Corynebacterium.

Strain $410^{\mathrm{T}}$ exhibited a complex polar lipid profile (Fig. 2). The major compounds were diphosphatidylglycerol, phosphatidylglycerol, phosphatidylinositol, four unidentified glycolipids (GL1-GL4) and two unidentified phospholipids (PL1, PL2). Minor amounts of four unidentified polar lipids (L1, L2, L3 and L4) that were not stainable with specific spray reagents such as molybdenum blue, ninhydrin or $\alpha-$ naphthol were also detected. Phosphatidylinositol mannosides, reported to be present in several Corynebacterium species (Fudou et al., 2002; Yassin et al., 2003; Chen et al., 2004), and also shown to be present in the reference species examined in the course of this study (Fig. 2), could not be detected. Obviously, this lipid is not generally found in Corynebacterium species or it is present in amounts that are below detection limit, as recently also shown for Corynebacterium lubricantis (Kämpfer et al., 2009). Strain $410^{\mathrm{T}}$ showed major differences in its polar lipid profile compared to its close relatives $C$. diphtheriae, $C$. 


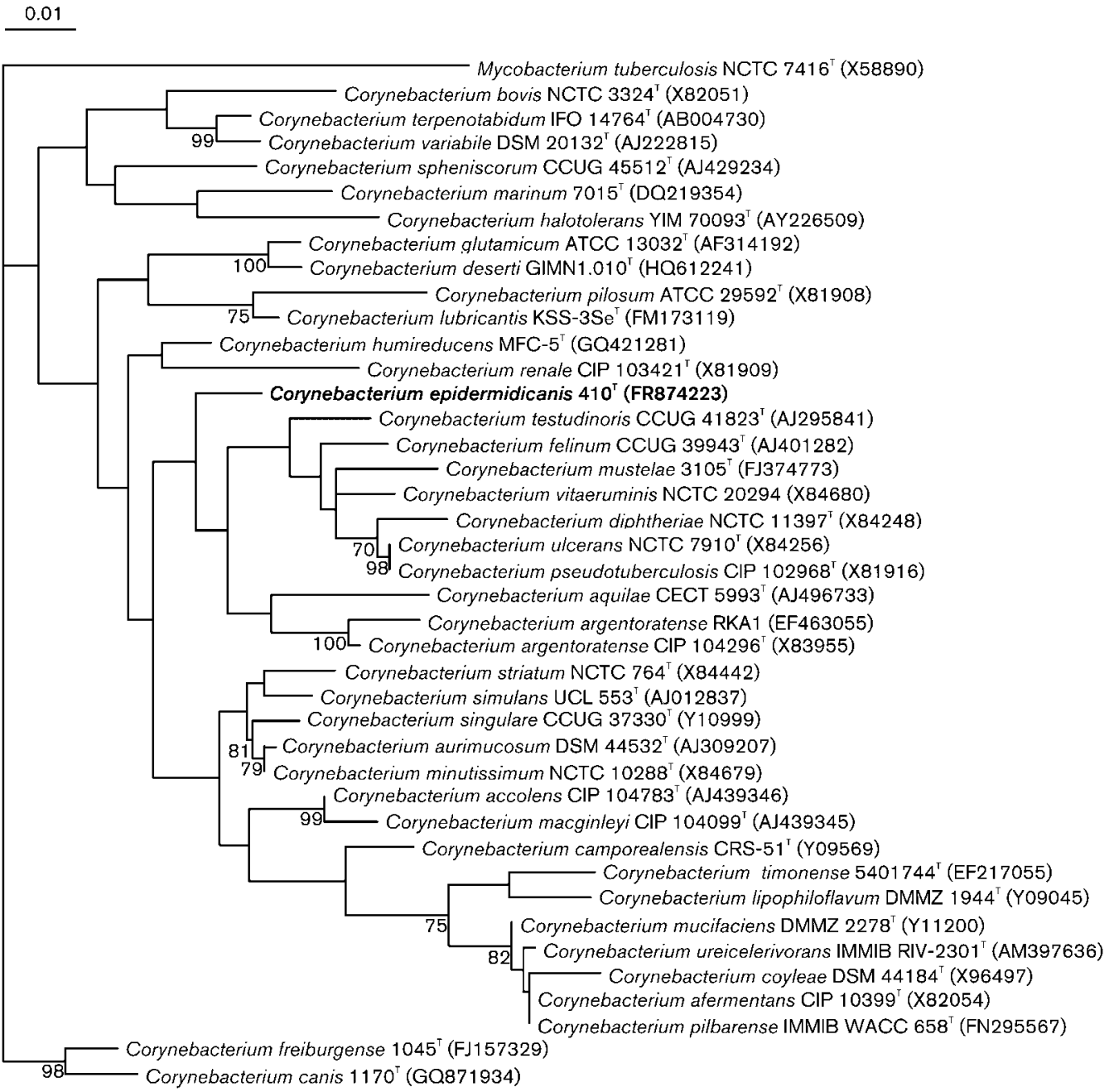

Fig. 1. Maximum-likelihood tree based on $16 \mathrm{~S}$ rRNA gene sequences showing the relatedness of strain $410^{\top}$ to Corynebacterium species that were selected based on sequence similarities with strain $410^{\top}$ higher than $95 \%$. Mycobacterium tuberculosis NCTC $7416^{\top}$ (X58890) was used as an outgroup. Bootstrap values (\%) $>70 \%$ based on 100 replicates are given at nodes. Bar, 0.01 substitutions per nucleotide position.

pseudotuberculosis, C. ulcerans and the more distantly related reference species Corynebacterium glutamicum (Fig. 2). It did not show the presence of phosphatidylinositol mannoside; the major glycolipids GL2 and GL3 were not detectable in any of the three reference species; glycolipid GL4 was only detected in C. glutamicum and glycolipid GL1 was only detected in C. glutamicum and C. diphtheriae. However, each of the reference species exhibited a distinctive polar lipid profile compared to the other reference species. C. pseudotuberculosis and C. ulcerans, which are phylogenetically most closely related to each other (Fig. 1), showed most similar lipid profiles, differing only in the presence of the minor lipids PL3 and L6 in C. ulcerans. These data indicate that, within the genus Corynebacterium, polar lipids reflect close phylogenetic relatedness but also that they have apparently a high discriminative power that may be useful for differentiation of less related species.
The polyamine pattern was composed of spermidine $\left[0.70 \mu \mathrm{mol}(\mathrm{g} \text { dry weight })^{-1}\right]$, spermine $[0.59 \mu \mathrm{mol}$ (g dry weight $\left.)^{-1}\right]$, putrescine $\left[0.36 \mu \mathrm{mol}(\mathrm{g} \text { dry weight })^{-1}\right], 1,3-$ diaminopropane $\left[0.05 \mu \mathrm{mol}(\mathrm{g} \text { dry weight })^{-1}\right]$ and cadaverine $\left[0.01 \mu \mathrm{mol}(\mathrm{g} \text { dry weight })^{-1}\right]$. This polyamine pattern is in line with characteristics reported for several Corynebacterium species (Altenburger et al., 1997).

Production of biomass, and extraction and analysis of fatty acids was carried out as described by Kämpfer \& Kroppenstedt (1996). The fatty acid profile (Table 1) was composed predominantly of straight-chain, saturated and mono-unsaturated fatty acids and major fatty acids were $\mathrm{C}_{18: 1} \omega 9 c, \mathrm{C}_{16: 1} \omega 7 c$ and $\mathrm{C}_{16: 0}$. Tuberculostearic acid could not be detected. This fatty acid profile was qualitatively quite similar to those of $C$. diphtheriae NCTC $11397^{\mathrm{T}}$, C. pseudotuberculosis DSM $20689^{\mathrm{T}}$ and C. ulcerans DSM $46325^{\mathrm{T}}$ 

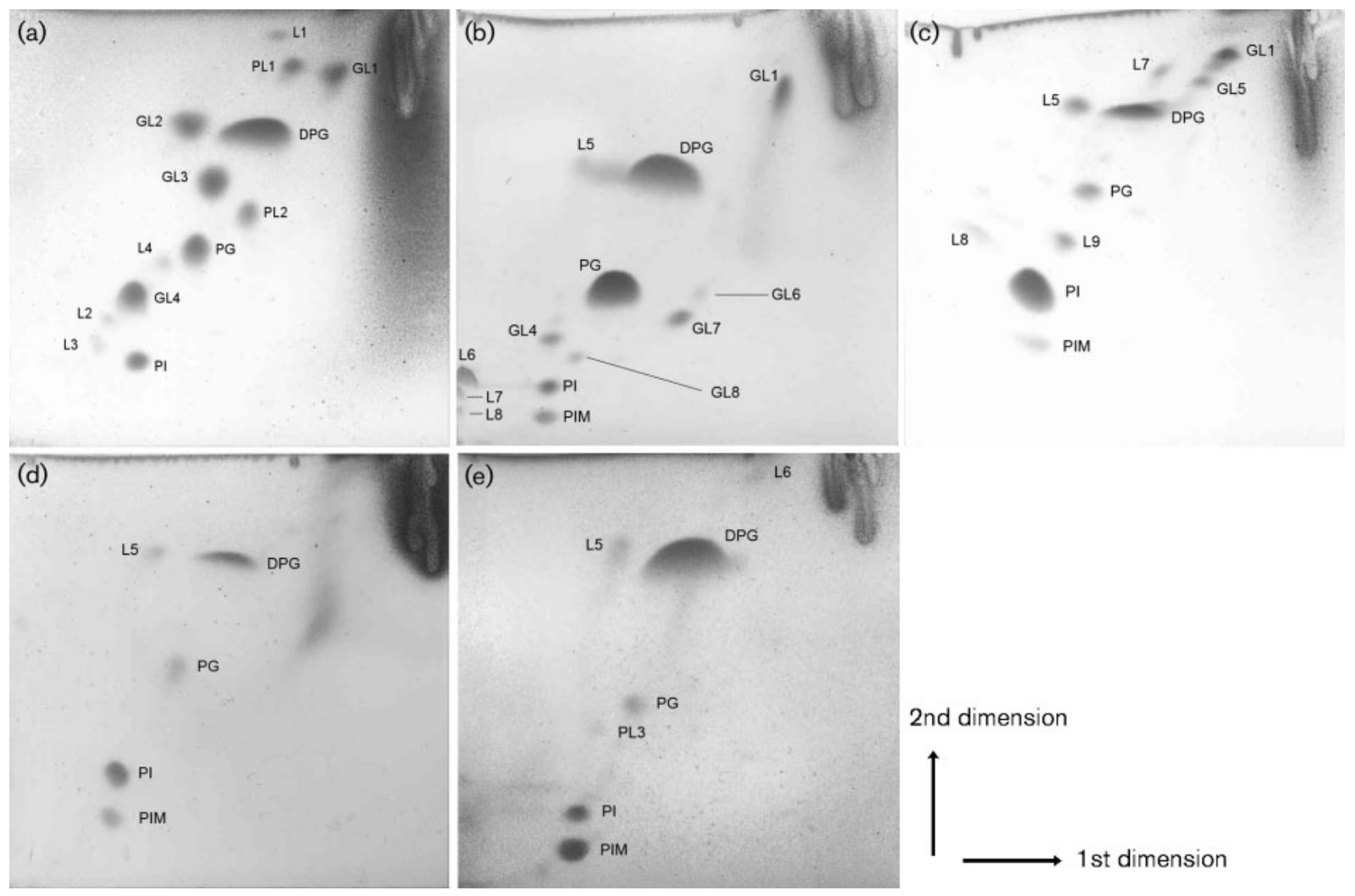

Fig. 2. Polar lipid profiles of strain $410^{\top}$ (a), C. glutamicum DSM $20300^{\top}$ (b), C. diphtheriae DSM $20524^{\top}$ (c), C. pseudotuberculosis DSM $20689^{\top}$ (d) and C. ulcerans DSM $46325^{\top}$ (e) after two-dimensional TLC and detection with molybdatophosphoric acid. DPG, Diphosphatidylglycerol; PG, phosphatidylglycerol; PI, phosphatidylinositol; PIM, phosphatidylinositol mannoside; GL1-GL8, unidentified glycolipids; L1-L8, unidentified lipids; PL1-PL3, unidentified phospholipids.

but the presence of major amounts of $\mathrm{C}_{16: 1} \omega 7 c$ clearly distinguished strain $410^{\mathrm{T}}$ from C. glutamicum DSM $20300^{\mathrm{T}}$ and C. humireducens MFC- $5^{\mathrm{T}}$ (Table 1). However, significant quantitative differences in the contents of several fatty acids, including $\mathrm{C}_{16: 0}$ and $\mathrm{C}_{18: 1} \omega 7 \mathrm{c}$, and the presence of $\mathrm{C}_{17: 1} \omega 8 c$ distinguished strain $410^{\mathrm{T}}$ from its close relatives.

Results of the comparative physiological characterization using identical test conditions (Kämpfer et al., 1991) for C. diphtheriae NCTC $11397^{\mathrm{T}}$, C. pseudotuberculosis DSM $20689^{\mathrm{T}}$, C. ulcerans DSM $46325^{\mathrm{T}}$ and C. glutamicum DSM $20300^{\mathrm{T}}$ are shown in Table 2.

Due to the close relatedness found between strain $410^{\mathrm{T}}$ and C. diphtheriae, production of diphtheria toxin was analysed. The toxigenicity testing was done according to the Manual for the Laboratory Diagnosis of Diphtheria by A. Efstratiou and P. A. C. Maple, WHO, Copenhagen 1994 (conventional test) and Engler et al. (1997) (modified Elek test). In both the conventional and modified Elek tests, no indication of toxigenicity was detected. These results were also confirmed in a PCR-based assay (results not shown) applying primers for the specific detection of the ' $\mathrm{A}$ ' portion of the toxin gene (Pallen et al., 1994) and primers for amplification of a 910 bp DNA fragment overlapping the $\mathrm{A}$ and $\mathrm{B}$ portions of the genes coding for diphtheria toxin (Hauser et al., 1993).

From the results from 16S rRNA gene analyses, and differences in phenotype (polar lipid and fatty acid profiles and physiology), it is obvious that strain $410^{\mathrm{T}}$ is different from C. diphtheriae, C. pseudotuberculosis, C. ulcerans and C. glutamicum and from other Corynebacterium species as well. In conclusion, strain $410^{\mathrm{T}}$ is a representative of a novel species of the genus Corynebacterium for which we propose the name Corynebacterium epidermidicanis sp. nov.

\section{Description of Corynebacterium epidermidicanis sp. nov.}

Corynebacterium epidermidicanis (e.pi.der.mi.di.ca'nis. L. n. epidermis -idis the surface, skin; L. n. canis -is a dog; N.L. gen. n. epidermidicanis of the skin of a dog).

Cells are pleomorphic (coccoid to rods) and non-motile with Gram-positive behaviour. Oxidase-negative. Good growth occurs on PYE agar and blood agar but not on MacConkey agar and it is able to grow under anaerobic conditions. Forms creamy-whitish, non-translucent colonies at $28^{\circ} \mathrm{C}$ on PYE agar with a diameter of approximately 
Table 1. Cellular fatty acid composition of strain $410^{\top}$ and related strains

Strains: $1,410^{\mathrm{T}} ; 2$, C. diphtheriae NCTC $11397^{\mathrm{T}} ; 3$, C. pseudotuberculosis DSM $20689^{\mathrm{T}} ; 4$, C. ulcerans DSM $46325^{\mathrm{T}} ; 5$, C. glutamicum DSM $20300^{\mathrm{T}} ; 6$, C. humireducens MFC- $5^{\mathrm{T}}$ [data from Wu et al. (2011)]. All data were from this study, except where marked. Data were obtained with the Sherlock MIDI version 2.1 (TSBA version 4.1). Empty cells indicate that the fatty acids were not detected.

\begin{tabular}{|lrccccc|}
\hline Fatty acid & $\mathbf{1}$ & $\mathbf{2}$ & $\mathbf{3}$ & $\mathbf{4}$ & $\mathbf{5}$ & $\mathbf{6}$ \\
\hline $\mathrm{C}_{14: 0}$ & & 1.8 & 2.9 & 4.6 & 0.8 & 1.6 \\
$\mathrm{C}_{15: 0}$ & 0.7 & & & & & \\
iso- $\mathrm{C}_{15: 0}$ & 1.0 & & & & & \\
$\mathrm{C}_{15: 1} \omega 6 c$ & 1.0 & & & & & \\
$\mathrm{C}_{16: 1} \omega 5 c$ & 3.1 & & & & & \\
$\mathrm{C}_{16: 1} \omega 9 c$ & & & & & 0.8 & \\
$\mathrm{C}_{16: 1} \omega 7 c^{*}$ & 25.3 & 36.3 & 33.6 & 30.6 & & \\
anteiso-C $17: 1 \omega 9 c$ & 1.5 & & & & & \\
$\mathrm{C}_{16: 0}$ & 18.0 & 42.6 & 51.6 & 45.2 & 42.6 & 33.7 \\
$\mathrm{C}_{18: 1} \omega 9 c$ & 30.6 & 15.4 & 9.4 & 17.6 & 53.6 & 42.7 \\
$\mathrm{C}_{18: 1} \omega 7 c$ & 2.6 & & & & & 1.7 \\
$\mathrm{C}_{17: 0}$ & & & & & 1.1 & 3.4 \\
$\mathrm{C}_{17: 1} \omega 8 c$ & 7.9 & & & & & 5.1 \\
$\mathrm{C}_{17: 1} \omega 6 c$ & 3.2 & & & & & \\
$\mathrm{C}_{18: 0}$ & 1.3 & 3.4 & 2.6 & 2.3 & 1.0 & 7.6 \\
\hline
\end{tabular}

${ }^{\star}$ The MIDI system identified this fatty acid as $\mathrm{C}_{16: 1} \omega 7 c$ and/or iso$\mathrm{C}_{15: 0}$ 2-OH. Since members of the genus Corynebacterium are known to lack hydroxy fatty acids, it is most likely that this fatty acid in fact is $\mathrm{C}_{16: 1} \omega 7 c$.

$0.5 \mathrm{~mm}$. The lipid profile consists of the major compounds diphosphatidylglycerol, phosphatidylglycerol, phosphatidylinositol, three glycolipids (GL2, GL3 and GL4), moderate amounts of two phospholipids (PL1 and PL2), a glycolipid (GL1) and minor amounts of four polar lipids not stainable with any specific detection reagent (L1, L2, L3 and L4). Major polyamines are spermine and spermidine. The quinone system is composed of predominantly MK-8 $\left(\mathrm{H}_{2}\right)$ and $\mathrm{MK}-9\left(\mathrm{H}_{2}\right)$. The fatty acid profile contains large amounts of $\mathrm{C}_{18: 1} \omega 9 c, \mathrm{C}_{16: 1} \omega 7 c$ and $\mathrm{C}_{16: 0 \text {. Tuberculostearic acid is }}$ absent.

Acetate, propionate, fumarate, L-aspartate, L-histidine and Lserine and trehalose (weakly) are assimilated but $N$-acetyl-Dgalactosamine, $N$-acetyl-D-glucosamine, L-arabinose, $p$-arbutin, cellobiose, gluconate, $\alpha$-melibiose, L-rhamnose, D-ribose, sucrose, salicin, D-xylose, adonitol, i-inositol, maltitol, Dmannitol, D-sorbitol, putrescine, cis-aconitate, trans-aconitate, adipate, 4-aminobutyrate, azelate, citrate, glutarate, DL-3-hydroxybutyrate, itaconate, mesaconate, oxoglutarate, suberate, L-alanine, $\beta$-alanine, L-leucine, L-ornithine, Lphenylalanine, L-proline, L-tryptophan, 3-hydroxybenzoate, 4-hydroxybenzoate and phenylacetate are not. In the miniaturized test system reported by Kämpfer et al. (1991), acid is not produced from glucose, lactose, sucrose, D-mannitol, dulcitol, salicin, adonitol, inositol, sorbitol,
Table 2. Physiological test results of strain $410^{\top}$ and related strains

Strains: $1,410^{\mathrm{T}} ; 2$, C. diphtheriae NCTC $11397^{\mathrm{T}} ; 3$, C. pseudotuberculosis DSM $20689^{\mathrm{T}}$; 4, C. ulcerans DSM $46325^{\mathrm{T}}$, 5, C. glutamicum DSM $20300^{\mathrm{T}}$. + , Positive; $(+)$, weakly positive; - , negative.

\begin{tabular}{|lccccc|}
\hline Test & $\mathbf{1}$ & $\mathbf{2}$ & $\mathbf{3}$ & $\mathbf{4}$ & $\mathbf{5}$ \\
\hline $\begin{array}{l}\text { NNP- } \alpha \text {-D- } \\
\text { glucopyranoside }\end{array}$ & - & $(+)$ & - & - & - \\
hydrolysis & & & & & \\
Assimilation of: & & & & & \\
$\quad$ D-Ribose & - & $(+)$ & + & + & + \\
Trehalose & $(+)$ & - & - & + & - \\
Acetate & + & $(+)$ & - & + & + \\
Propionate & + & - & - & + & + \\
Fumarate & + & - & + & + & + \\
L-Aspartate & + & $(+)$ & + & + & + \\
L-Histidine & + & - & - & - & - \\
L-Serine & + & - & $(+)$ & - & $(+)$ \\
& & & & & \\
\hline
\end{tabular}

L-arabinose, raffinose, rhamnose, maltose, D-xylose, trehalose, cellobiose, methyl D-glucoside, erythritol, melibiose, $\mathrm{D}$-arabitol or D-mannitol. Aesculin, para-nitrophenyl ( $p \mathrm{NP})$ $\beta$-D-galactopyranoside, $p \mathrm{NP}-\beta$-D-glucuronide, $\quad p \mathrm{NP}-\alpha$-Dglucopyranoside, $p \mathrm{NP}-\beta$-D-glucopyranoside, $p \mathrm{NP}-\beta$-D-xylopyranoside, bis- $p$ NP-phosphate, $p$ NP-phenyl-phosphonate, pNP-phosphoryl-choline, 2-deoxythymidine-5' - $p$ NP-phosphate and L-glutamate- $\gamma-3$-carboxy- $p$-nitroanilide are not hydrolysed.

In the ApiCoryne test, produces acid from the carbohydrates D-glucose and maltose, whereas no acid is produced from D-ribose, D-xylose, D-mannitol, lactose, sucrose or glycogen. Alkaline phosphatase and pyrazinamidase are positive, whereas $\beta$-glucuronidase, $\beta$-galactosidase, $\alpha$-glucosidase, $N$-acetylglucosaminidase and urease production are negative. Nitrate reduction and aesculin and gelatin hydrolysis are negative; catalase is positive. Non-lipophilic and the CAMP reaction is positive. The resulting ApiCoryne code is 2100124. Diphtheria toxin is absent.

The type strain is $410^{\mathrm{T}}\left(=\mathrm{DSM} 45586^{\mathrm{T}}=\mathrm{LMG} 26322^{\mathrm{T}}=\right.$ CCUG $60915^{\mathrm{T}}$ ), isolated in Austria from the skin of a dog suffering from pruritus.

\section{Acknowledgements}

We are grateful to Jean Euzéby for advice in etymology and nomenclature.

\section{References}

Altenburger, P., Kämpfer, P., Makristathis, A., Lubitz, W. \& Busse, H.-J. (1996). Classification of bacteria isolated from a medieval wall painting. J Biotechnol 47, 39-52.

Altenburger, P., Kämpfer, P., Akimov, V. N., Lubitz, W. \& Busse, H.-J. (1997). Polyamine distribution in actinomycetes with group $B$ 
peptidoglycan and species of the genera Brevibacterium, Corynebacterium, and Tsukamurella. Int J Syst Bacteriol 47, 270-277.

Aravena-Roman, M., Spröer, C., Sträubler, B., Inglis, T. \& Yassin, A. F. (2010). Corynebacterium pilbarense sp. nov., a non-lipophilic corynebacterium isolated from a human ankle aspirate. Int J Syst Evol Microbiol 60, 1484-1487.

Bernard, K. A., Wiebe, D., Burdz, T., Reimer, A., Ng, B., Singh, C., Schindle, S. \& Pacheco, A. L. (2010). Assignment of Brevibacterium stationis (ZoBell and Upham 1944) Breed 1953 to the genus Corynebacterium, as Corynebacterium stationis comb. nov., and emended description of the genus Corynebacterium to include isolates that can alkalinize citrate. Int J Syst Evol Microbiol 60, 874879.

Buczolits, S., Schumann, P., Valens, M., Rosselló-Mora, R. \& Busse, H.-J. (2008). Identification of a bacterial strain isolated from the liver of a laboratory mouse as Microbacterium paraoxydans and emended description of the species Microbacterium paraoxydans Laffineur et al. 2003. Indian J Microbiol 48, 243-251.

Busse, H.-J. \& Auling, G. (1988). Polyamine pattern as a chemotaxonomic marker within the Proteobacteria. Syst Appl Microbiol 11, $1-8$.

Chen, H.-H., Li, W.-J., Tang, S.-K., Kroppenstedt, R. M., Stackebrandt, E., Xu, L.-H. \& Jiang, C.-L. (2004). Corynebacterium halotolerans sp. nov., isolated from saline soil in the west of China. Int J Syst Evol Microbiol 54, 779-782.

Chun, J., Lee, J. H., Jung, Y., Kim, M., Kim, S., Kim, B. K. \& Lim, Y. W. (2007). EzTaxon: a web-based tool for the identification of prokaryotes based on 16S ribosomal RNA gene sequences. Int J Syst Evol Microbiol 57, 2259-2261.

Collins, M. D. \& Jones, D. (1981). The distribution of isoprenoid quinone structural type in bacteria and their taxonomic implications. Microbiol Rev 45, 316-354.

Collins, M. D., Goodfellow, M. \& Minnikin, D. E. (1982a). A survey of the structures of mycolic acids in Corynebacterium and related taxa. J Gen Microbiol 128, 129-149.

Collins, M. D., Goodfellow, M. \& Minnikin, D. E. (1982b). Fatty acid composition of some mycolic acid-containing coryneform bacteria. J Gen Microbiol 128, 2503-2509.

Collins, M. D., Burton, R. A. \& Jones, D. (1988). Corynebacterium amycolatum sp. nov., a new mycolic acid-less Corynebacterium species from human skin. FEMS Microbiol Lett 49, 349-352.

Collins, M. D., Falsen, E., Akervall, E., Sjöden, B. \& Alvarez, A. (1998). Corynebacterium kroppenstedtii sp. nov., a novel corynebacterium that does not contain mycolic acids. Int J Syst Bacteriol 48, 1449-1454.

Collins, M. D., Hoyles, L., Foster, G. \& Falsen, E. (2004). Corynebacterium caspium sp. nov., from a Caspian seal (Phoca caspica). Int J Syst Evol Microbiol 54, 925-928.

Du, Z.-J., Jordan, E. M., Rooney, A. P., Chen, G.-J. \& Austin, B. (2010). Corynebacterium marinum sp. nov., isolated from coastal sediment. Int J Syst Evol Microbiol 60, 1944-1947.

Engler, K. H., Glushkevich, T., Mazurova, I. K., George, R. C. \& Efstratiou, A. (1997). A modified Elek test for detection of toxigenic corynebacteria in the diagnostic laboratory. J Clin Microbiol 35, 495498.

Felsenstein, J. (2009). PHYLIP (phylogeny inference package) version 3.69. Distributed by the author. Department of Genome Sciences, University of Washington, Seattle, USA.

Fernández-Garayzábal, J. F., Vela, A. I., Egido, R., Hutson, R. A., Lanzarot, M. P., Fernández-Garcia, M. \& Collins, M. D. (2004). Corynebacterium ciconiae sp. nov., isolated from the trachea of black storks (Ciconia nigra). Int J Syst Evol Microbiol 54, 2191-2195.
Fudou, R., Jojima, Y., Seto, A., Yamada, K., Kimura, E., Nakamatsu, T., Hiraishi, A. \& Yamanaka, S. (2002). Corynebacterium efficiens sp. nov., a glutamic-acid-producing species from soil and vegetables. Int J Syst Evol Microbiol 52, 1127-1131.

Funke, G., Englert, R., Frodl, R., Bernard, K. A. \& Stenger, S. (2010a). Corynebacterium canis sp. nov., isolated from a wound infection caused by a dog bite. Int J Syst Evol Microbiol 60, 2544-2547.

Funke, G., Frodl, R. \& Bernard, K. A. (2010b). Corynebacterium mustelae sp. nov., isolated from a ferret with lethal sepsis. Int J Syst Evol Microbiol 60, 871-873.

Hall, T. A. (1999). BioEdit: a user-friendly biological sequence alignment editor and analysis program for Windows 95/98/NT. Nucleic Acids Symp Ser 41, 95-98.

Hall, V., Collins, M. D., Hutson, R. A., Lawson, P. A., Falsen, E. \& Duerden, B. I. (2003). Corynebacterium atypicum sp. nov., from a human clinical source, does not contain corynomycolic acids. Int $J$ Syst Evol Microbiol 53, 1065-1068.

Hauser, D., Popoff, M. R., Kiredjian, M., Boquet, P. \& Bimet, F. (1993). Polymerase chain reaction assay for diagnosis of potentially toxinogenic Corynebacterium diphtheriae strains: correlation with ADP-ribosylation activity assay. J Clin Microbiol 31, 2720-2723.

Hilbert, F., Scherwitzel, M., Paulsen, P. \& Szostak, M. P. (2010). Survival of Campylobacter jejuni under conditions of atmospheric oxygen tension with the support of Pseudomonas spp. Appl Environ Microbiol 76, 5911-5917.

Kämpfer, P. \& Kroppenstedt, R. M. (1996). Numerical analysis of fatty acid patterns of coryneform bacteria and related taxa. Can $J$ Microbiol 42, 989-1005.

Kämpfer, P., Steiof, M. \& Dott, W. (1991). Microbiological characterization of a fuel-oil contaminated site including numerical identification of heterotrophic water and soil bacteria. Microb Ecol 21, 227-251.

Kämpfer, P., Lodders, N., Warfolomeow, I., Falsen, E. \& Busse, H.-J. (2009). Corynebacterium lubricantis sp. nov., isolated from a coolant lubricant. Int J Syst Evol Microbiol 59, 1112-1115.

Lane, D. J. (1991). 16S/23S rRNA sequencing. In Nucleic Acid Techniques in Bacterial Systematics, pp. 115-175. Edited by E. Stackebrandt \& M. Goodfellow. Chichester: Wiley.

Moaledj, K. (1986). Comparison of Gram-staining and alternate methods, $\mathrm{KOH}$ test and aminopeptidase activity in aquatic bacteria: their application to numerical taxonomy. J Microbiol Methods 5, 303-310.

Murray, R. G. E., Doetsch, R. N. \& Robinow, C. F. (1994). Methods for General and Molecular Bacteriology, pp. 21-41. Edited by P. Gerhardt, R. G. E. Murray, W. A. Wood \& N. R. Krieg. Washington, DC: American Society for Microbiology.

Pallen, M. J., Hay, A. J., Puckey, L. H. \& Efstratiou, A. (1994). Polymerase chain reaction for screening clinical isolates of corynebacteria for the production of diphtheria toxin. J Clin Pathol 47, 353-356.

Pearson, W. R. \& Lipman, D. J. (1988). Improved tools for biological sequence comparison. Proc Natl Acad Sci U S A 85, 2444-2448.

Schleifer, K. H. \& Kandler, O. (1972). Peptidoglycan types of bacterial cell walls and their taxonomic implications. Bacteriol Rev 36, 407-477.

Stolz, A., Busse, H.-J. \& Kämpfer, P. (2007). Pseudomonas knackmussii sp. nov. Int J Syst Evol Microbiol 57, 572-576.

Thompson, J. D., Gibson, T. J., Plewniak, F., Jeanmougin, F. \& Higgins, D. G. (1997). The CLUSTAL_X windows interface: flexible strategies for multiple sequence alignment aided by quality analysis tools. Nucleic Acids Res 25, 4876-4882.

Tindall, B. J. (1990a). Lipid composition of Halobacterium lacusprofundi. FEMS Microbiol Lett 66, 199-202. 
Tindall, B. J. (1990b). A comparative study of the lipid composition of Halobacterium saccharovorum from various sources. Syst Appl Microbiol 13, 128-130.

Tong, J., Liu, C., Summanen, P. H., Xu, H. \& Finegold, S. M. (2010). Corynebacterium pyruviciproducens sp. nov., a pyruvic acid producer. Int J Syst Evol Microbiol 60, 1135-1140.
Wu, C.-Y., Zhuang, L., Zhou, S. G., Li, F.-B. \& He, J. (2011). Corynebacterium humireducens sp. nov., an alkaliphilic, humic acid-reducing bacterium isolated from a microbial fuel cell. Int $J$ Syst Evol Microbiol 61, 882-887.

Yassin, A. F., Kroppenstedt, R. M. \& Ludwig, W. (2003). Corynebacterium glaucum sp. nov. Int J Syst Evol Microbiol 53, 705-709. 